\title{
Chondroitin Sulfate Proteoglycan and Tenascin in the Wounded Adult Mouse Neostriatum In Vitro: Dopamine Neuron Attachment and Process Outgrowth
}

\author{
Monte A. Gates, Helen Fillmore, and Dennis A. Steindler \\ Department of Anatomy and Neurobiology, University of Tennessee, Memphis, Tennessee 38163
}

\begin{abstract}
Extracellular matrix (ECM) molecules, including chondroitin-4 or chondroitin- 6 sulfate proteoglycans (CSPGs) and tenascin, are upregulated in and around wounds and transplants to the adult CNS. In the present study, striatal wounds from adult mice were used in a novel in vitro paradigm to assess the effects of these wound-associated molecules on embryonic dopamine cell attachment and neurite outgrowth. Light and electron microscopic immunocytochemistry studies have shown that astroglial scar constituents persist in cultured explants for at least 1 week in vitro, and despite the loss of neurons from adult striatal explants, there is a retention of certain structural features suggesting that the wound explantneuron coplant is a viable model for analysis of graft-scar interactions. Explants from the wounded striatum taken at different times after a penetrating injury in vivo were used as
\end{abstract}

substrates for embryonic ventral mesencephalon neurons that were plated on their surfaces. Dopamine cell attachment is increased significantly in relation to the expression of both CSPG and tenascin. The increase in neuronal attachment in this paradigm, however, is accompanied by a postlesion survival time-dependent significant decrease in neuritic growth from these cells. In vitro ECM antibody treatment suggests that CSPG may be responsible for heightened dopamine cell attachment and that tenascin simultaneously may support cell attachment while inhibiting neurite growth. The present study offers a new approach for the in vitro analysis of cell and molecular interactions after brain injury and brain grafting, in essence acting as a nigrostriatal transplant-in-a-dish.

Key words: extracellular matrix; explant culture; brain injury; dopamine neurons; cell-substrate interactions; neurite growth
Cellular and molecular analyses of adult brain wounds have generated a list of numerous astrocyte and oligodendrocyte proteins that might contribute to predominantly unfavorable neurite growth conditions in and around a lesion site (Brodkey et al., 1993; Schwab et al., 1993; Steindler, 1993). Adult neurons, when given a suitable substrate, can extend processes over considerable distances in the wounded adult spinal cord (Aguayo et al., 1981; David and Aguayo, 1981; Fawcett, 1989; Schnell and Schwab, 1990). The so-called regenerative failure in the adult CNS therefore does not seem to result from neurons that are unable to initiate neurite growth, but rather from factors that are associated with a wound or graft site that may be neurite growth-inhibiting (Smith et al., 1986; Rudge et al., 1989; Rudge and Silver, 1990; Laywell and Steindler, 1991; McKeon et al., 1991; Laywell et al., 1992; Gates et al., 1996).

Extracellular matrix (ECM) molecules such as tenascin and chondroitin sulfate proteoglycans (CSPGs) are expressed prominently during CNS development but are downregulated in the adult brain (Crossin et al., 1986; Steindler et al., 1989a,b, 1990). Traumatic injuries to the adult CNS lead to the apparent en-

\footnotetext{
Received Aug. 14, 1996; revised Oct. 1, 1996; accepted Oct. 3, 1996.

This work was supported by National Institutes of Health/National Institute of Neurological Disorders and Stroke Grant NS29225. We thank Donna J. Gates for her exceptional technical work and Drs. L. Brannon Thomas, Eric D. Laywell, and Kristine Harrington for their critical analysis of these studies.

Correspondence should be addressed to Dr. Dennis A. Steindler, Department of Anatomy and Neurobiology, University of Tennessee at Memphis, College of Medicine, 855 Monroe Avenue, Memphis, TN 38163.

Dr. Gates' current address: Department of Medical Cell Research, University of Lund, Biskopegatan 5, 62 Lund, Sweden.

Dr. Fillmore's current address: Department of Neurosurgery, Medical College of Virginia, 1200 East Broad Street, Richmond, VA 23298.

Copyright (C) 1996 Society for Neuroscience $0270-6474 / 96 / 168005-14 \$ 05.00 / 0$
}

hanced expression of ECM as well as other astroglial proteins (Bignami and Dahl, 1976; Eng, 1988; McKeon et al., 1991; Laywell et al., 1992; Eddelston and Mucke, 1993; Brodkey et al., 1995). Although reactive (e.g., GFAP-positive) glial cells within and around a lesion site can facilitate certain aspects of the wound healing process (for review, see Brodkey et al., 1993), overall, reactive gliosis is presumed to contribute to a barrier that impedes neurite growth or regrowth. It is perplexing, then, to understand how glial cells that may support neural cell migration and growth during development can, somehow, be involved in failed neuronal regenerative responses in the adult CNS. It has been shown that the state of maturation as well as reactivity of astrocytes can affect the attachment and growth of CNS neurons in coculture studies (Lindsay, 1979; Lindsay et al., 1982; Hatten et al., 1991; Gates et al., 1993; Le Roux and Reh, 1994). CSPGs have been suggested to both inhibit as well as provide a favorable substrate for the growth of neurites in vitro and in vivo (Snow et al., 1990a,b; Snow and Letourneau, 1992; Bicknese et al., 1994; Faissner et al., 1994). These variable responses may depend on the particular neuronal or glial population involved (Denis-Donini et al., 1984; Chamak et al., 1987; Chamak and Prochiantz, 1989; Qian et al., 1992; Le Roux and Reh, 1994) or even on specific isoforms or regions of the individual molecules that are assayed (Spring et al., 1989; Aukhil et al., 1993; Dorries et al., 1996; Gotz et al., 1996).

The present study has characterized the expression of CSPG and tenascin in astroglial scars from the adult mouse striatum, using a novel in vitro paradigm of plating dissociated embryonic ventral mesencephalon (VM) cells on the surface of explants from the wounded adult striatum. Dopamine cell attachment and process outgrowth were measured in response to the presence or absence of either CSPG or tenascin on wounded, unwounded, and 


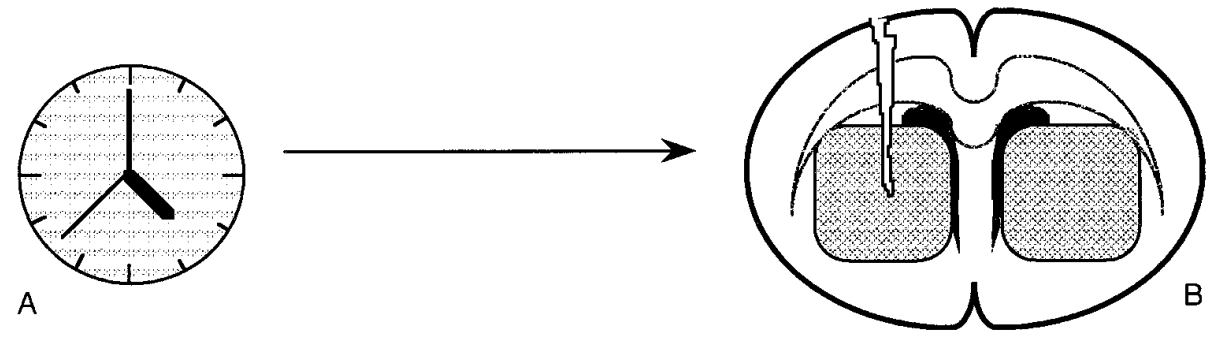

Figure 1. Diagram depicting the approach used in culturing explants of adult striatal wounds as substrates for embryonic ventral mesencephalon (VM) cells. After different survival times in vivo $(A)$, striatal stab wounds $(B)$ are isolated from fresh postmortem mouse brains using $300-400-\mu \mathrm{m}$-thick slices $(C)$ that are separated from each other after sectioning on a tissue chopper. The region just around the penetrating injury site is further dissected free from surrounding structures with microknives $(D)$; these wounds are cultured on Millicell insert filters in culture dishes $(E)$ with or without the plating of embryonic VM cells and, in certain studies, preincubated in antibodies or control immunoglobulins.
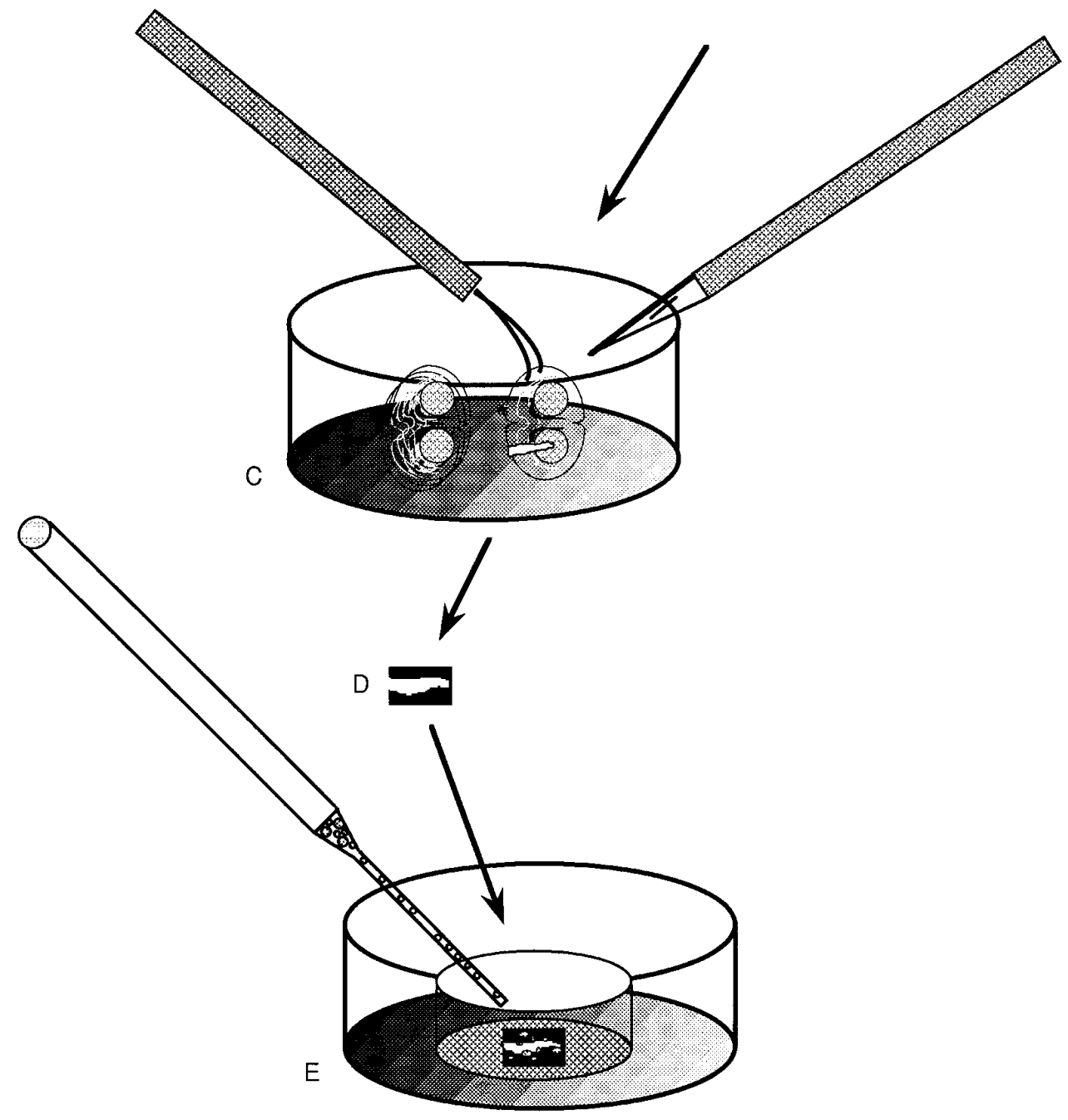

antibody-treated striatal substrates. The choice of embryonic dopamine neurons and the adult striatum in this coculturing paradigm pertains to the well established use of embryonic dopamine neurons for transplantation into the adult striatum in Parkinson's disease and animal models of the disease (Bjorklund et al., 1983), by which reactive astrocytes and ECM may affect graft survival and integration (Gates et al., 1996).

\section{MATERIALS AND METHODS}

The basic paradigm used in this study is presented in Figure 1. Following different survival times (Fig. 1 $A$ ) after penetrating stab lesions of the striatum (Fig. $1 B$ ), sections through the lesioned or normal striatum were collected for immunocytochemistry or explanting (Fig. 1C). Isolated glial scars were studied to determine the persistence of wound-associated ECM molecules and assayed further for their ability to act as substrates for the attachment and growth of embryonic VM neurons (Fig. 1D,E).

Normal and wounded adult mouse striatal explants. Adult ICR mice (i.e. $>60 \mathrm{~d}$ old $)$ were anesthetized with Avertin $(100 \mu \mathrm{l} / \mathrm{gm}$ body weight $)$ and secured in a stereotaxic apparatus. A 27 gauge needle was lowered $\sim 3.0$ $\mathrm{mm}$ dorsoventral from the surface of the brain (coordinates ${ }^{+} 0.3 \mathrm{~mm}$ caudorostral from Bregma and $2.5 \mathrm{~mm}$ mediolateral) to create a lesion in the neostriatum. Control (i.e., sham-operated) animals were anesthetized, and only holes were drilled into the skull at the same coordinates. Striatal lesioned postnatal day 6 animals $(n<10)$ also were used to generate explant substrates.

Brain specimens were prepared from mice $(n \sim 60)$ with postlesion survivals from $1 \mathrm{hr}$ to $10 \mathrm{~d}$. Fresh brain specimens were mounted on a vibratome; $250-300 \mu \mathrm{m}$ coronal sections were cut through the wounded and normal striatum ( $\sim 2-3$ sections per specimen), and they were placed in an ice-cold stabilizing solution consisting of 4.5 gm $\beta$-D-glucose/1 1 Gey's Balanced Salt Solution (GBSS; Life Technologies, Gaithersburg, $\mathrm{MD})$. The sections were rinsed in fresh GBSS, and the lesioned area or central portion of the nonlesioned striatum was dissected away (the center of the lesion was recognized by the presence of blood and refractive cellular debris). Some explants $(n \sim 20)$ were transferred to a $4 \%$ paraformaldehyde (4\% PF) fixative to be processed further for immunocytochemistry (see below). Other wounded $(n \sim 60)$ and sham-operated 
$(n \sim 20)$ striatal explants were incubated for $2-3 \mathrm{hr}$ in a conical tube containing fresh GBSS alone or an antibody solution of anti-GFAP (1:100; Shandon-Lipshaw, Pittsburgh, PA), a monoclonal antibody to the glial-fibrillary acidic protein (Bignami and Dahl, 1974); anti-CS-56 (1:200; Sigma, St. Louis, MO), a monoclonal antibody that reacts specifically with chondroitin sulfate types A and C (but not B, dermatan sulfate) containing proteoglycans (Avnur and Geiger, 1984); or anti-tenascin antibodies (generous gifts of Dr. M. Schachner, ETH, Zurich, Switzerland, and A. Faissner, University of Heidelberg, Germany), a polyclonal antibody to a bacterially expressed tenascin fusion protein (Steindler et al., 1995; Dorries et al., 1996), previously used in an in vitro bioassay with cryocultures (Laywell et al., 1996), as well as purified antigen-binding fragments (fabs) generated from polyclonal anti-tenascin IgGs. Normal rabbit serum, a rat monoclonal IgM antibody to radial glia [RC-2 (Edwards et al., 1990), a generous gift from Dr. Jim Crandall, Shriver Center, Waltham, MA] and mouse IgM (purified protein; Chemicon, Temecula, CA) were chosen as controls because the $\mathrm{pk} 7 \mathrm{ab}$ is a rabbit polyclonal antibody and the CS-56 monoclonal antibody $(\mathrm{mAb})$ is an $\operatorname{IgM}$ monoclonal. A final control for the CS-56 mAb perturbation experiments was to incubate some wound slices in the presence of both the $\mathrm{mAb}$ and chondroitin sulfate $\mathrm{C}$ (sodium salt, from Shark cartilage, $500 \mu \mathrm{g} / \mathrm{ml}$; Sigma). Explant slices were rinsed in fresh PBS and laid flat on Millicell membranes (Millipore, Bedford, MA) saturated with media $(50 \%$ DMEM/F12, 30\% HBSS, and $20 \%$ fetal calf serum) in $60 \mathrm{~mm}$ Petri dishes. Explants were incubated at $37^{\circ} \mathrm{C}$ with $95 \%$ humidity $/ 5 \% \mathrm{CO}_{2}$ while embryonic neurons were dissected and dissociated (usually $\sim 45 \mathrm{~min}-1 \mathrm{hr}$ ).

Immunoprecipitation and Western blotting studies of tenascin in normal and wounded striatum. One of the tenascin antibodies used in immunocytochemistry and antibody perturbation experiments also was used in protein electrophoresis studies to determine its ability to recognize tenascin from normal and injured mouse brain. Tissue from the early postnatal and adult cerebellum and olfactory bulb and tissue from normal and lesioned adult neostriatum (needle stab wounds; $3 \mathrm{~d}$ survival) were homogenized in $50 \mathrm{~mm}$ Tris buffer, $\mathrm{pH} 7.4,150 \mathrm{~mm} \mathrm{NaCl}, 2 \mathrm{M}$ urea, 2 $\mu \mathrm{g} / \mathrm{ml}$ leupeptin, $0.5 \%$ aprotinin, $1 \mathrm{~mm}$ PMSF, $2 \mathrm{~mm}$ EDTA, and $1 \mathrm{~mm}$ NaVandate. Protein concentrations were determined with the detergentcompatible (DC) assay. Lysates were normalized on an equal protein basis before immunoprecipitation. A polyclonal antibody to a bacterially expressed tenascin fusion protein (Steindler et al., 1995; Dorries et al., 1996; Laywell et al., 1996) was added to the cell lysates at a concentration of $10 \mu \mathrm{g} / \mathrm{ml}$ and incubated at $4^{\circ} \mathrm{C}$ with agitation for $2 \mathrm{hr}$. The antibody/ protein complex was purified by protein A-Sepharose CL-4B affinity chromatography (Pharmacia, Piscataway, NJ). Proteins were immunoprecipitated by addition of $10 \mu \mathrm{l}$ of the protein A-Sepharose to cleared cell lysates, followed by end-over-end mixing for $2 \mathrm{hr}$ at $4^{\circ} \mathrm{C}$. The immunoprecipitates were washed $5 \times$ in buffer and boiled for $1 \mathrm{~min}$ in Laemmli sample buffer; the eluted proteins were separated electrophoretically on $10 \%$ polyacrylamide sodium dodecyl sulfate gels with a minigel apparatus (Aquebogue Machine Shop, Aquebogue, New York) and compared with protein standards (myosin, $207 \mathrm{kDa} ; \beta$-galactosidase, $139 \mathrm{kDa}$; BSA, 84 $\mathrm{kDa}$; Bio-Rad, Richmond, CA). Proteins were transferred to nitrocellulose with Tris-glycine and methanol (using a Bio-Rad Mini Protean II, transferred for $6-7 \mathrm{hr}$ ). The nitrocellulose was incubated for $1 \mathrm{hr}$ in 50 $\mathrm{mm}$ Tris and $150 \mathrm{~mm} \mathrm{NaCl}$ (TBS), $\mathrm{pH} 7.4$, containing 3\% powdered milk to block nonspecific antibody binding and then incubated overnight at $4^{\circ}$ $\mathrm{C}$ in the same solution containing $5 \mu \mathrm{g} / \mathrm{ml}$ of the polyclonal tenascin antibody. After they were rinsed with TBS, the nitrocellulose filters were incubated for $2 \mathrm{hr}$ at room temperature with peroxidase-conjugated goat anti-rabbit IgG diluted 1:5000 and processed further for peroxidase chemistry.

Immunoprecipitation and Western blot studies consistently revealed the presence of two major and possibly a single or doublet minor bands at $\sim 200,190$, and $240-280 \mathrm{kDa}$, respectively, for most of the adult CNS structures examined (Fig. 2). Under the biochemical conditions described here, where different amounts of protein were used from the adult olfactory bulb, normal and wounded striatum, postnatal day 5 whole brain, and adult cerebellum, all structures seemed to possess the higher molecular weight forms (especially the P5 whole brain), except for the adult cerebellum (despite overloading with the same amount of protein as used from the P5 brain, the higher molecular weight band was less obvious, but the presence of some very light low molecular weight bands may represent breakdown products; see Fig. 2). These findings indicate that one of the antibodies used in the perturbation experiments described below does, in fact, recognize tenascin as described in previous studies, if molecular weight forms of the glycoprotein from different rodent CNS

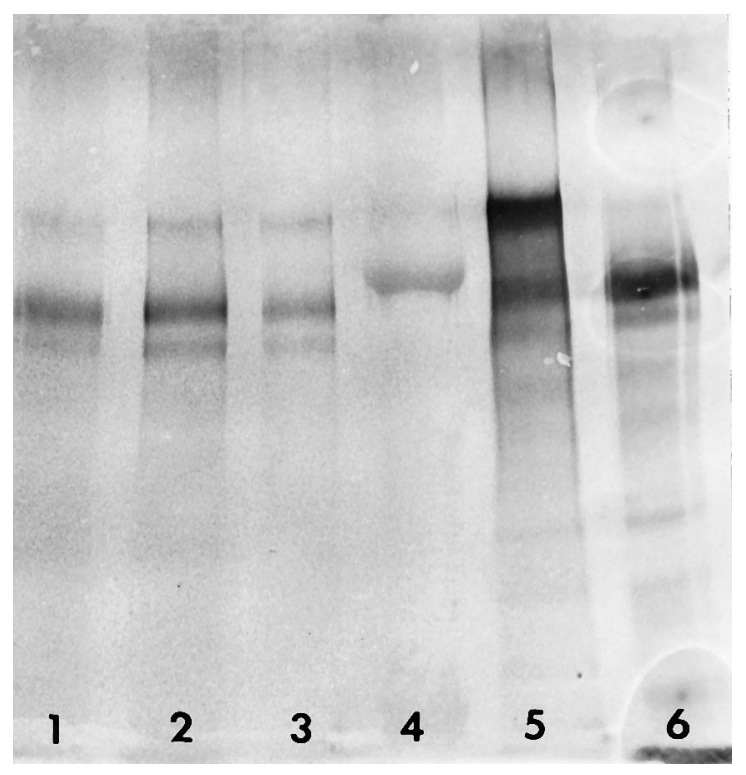

Figure 2. Immunoprecipitation and Western blot of extracts taken from different developing and lesioned mouse brain areas by the polyclonal antibody to tenascin, as used in immunocytochemistry and antibody perturbation experiments shown in all other figures. Lane 1, Olfactory bulb [protein immunoprecipitation (IP), $912 \mu \mathrm{g}$ ]; lane 2, adult wounded striatum (protein IP, $1 \mathrm{mg}$ ); lane 3, adult normal striatum (protein IP, $306 \mu \mathrm{g}$ ); lane 4, molecular weight standard, $207 \mathrm{kDa}$; lane 5, postnatal day 5 whole brain (protein IP, $1.7 \mathrm{mg}$ ); lane 6, cerebellum (protein IP, $1.8 \mathrm{mg}$ ).

regions are considered (Chiquet-Ehrismann, 1990; Faissner and Kruse, 1990; Weller et al., 1991; Meiners et al., 1995).

Harvesting embryonic VM cells. Embryonic cells, to be plated on the explant substrates described above, were obtained from embryonic day 14 or 15 (E14-E15) mouse VM (Bjorklund et al., 1983). Briefly, ICR mice (E14-E15; Harlan Sprague Dawley, Indianapolis, IN) were anesthetized with Avertin. Fetuses were removed via cesarean sectioning and placed in a large Petri dish containing ice-cold GBSS. A midline sagittal incision was made through the scalp of each embryo, and the brain was removed. Brains were bisected in the midsagittal plane with a microknife, and the pia was peeled away. A $1-2 \mathrm{~mm}^{3}$ block was cut from the area of the VM and transferred into a conical $15 \mathrm{ml}$ tube containing ice-cold GBSS Blocks obtained from a single litter (usually $\sim 20-24$ pieces) were triturated via a series of fire-polished pipettes with progressively smaller tips. Cells were checked for viability and counted by using trypan blue (Life Technologies) staining and a hemacytometer. Approximately a $5 \mu$ ldrop of the cell suspension $(\sim 40,000-60,000$ cells $)$ was placed on the surfaces of most explants from the normal, wounded, and antibody-perturbated/ wounded adult striatum.

Immunocytochemistry for astroglia and ECM associated with wounded and unwounded substrates. All explants were fixed overnight in ice-cold $4 \%$ PF. The next day explants were rinsed $3 \times$ in fresh PBS and (for all explants not exposed to antibodies, herein referred to as untreated) incubated for $24 \mathrm{hr}$ in one of the following concentrations of antibodies in PBS: GFAP, 1:100; CS-56, 1:200; or polyclonal tenascin, 1:500. Explants that were antibody-perturbated, as well as untreated explants incubated overnight in primary antibodies, were placed in a complementary secondary antibody conjugated to either 7-amino-4-methylcoumarin3-acetic acid (AMCA) (for GFAP), rhodamine (for CS-56), or fluorescein (for anti-tenascin) for $3 \mathrm{hr}$ at room temperature. Explants subsequently were rinsed in fresh PBS, mounted, and coverslipped on gelatinized slides and viewed through a Leitz fluorescence microscope.

Tyrosine hydroxylase immunocytochemistry of cocultures. After 5-9 d in vitro, inserts supporting cocultures of wounded and unwounded adult striatum and dissociated VM were removed from their Petri dishes, and the mesh filters were peeled away gently from the plastic frames with forceps. The filters were submerged in ice-cold $4 \% \mathrm{PF}$, and the explants were detached from the mesh with a fine brush (many times brushing was not necessary, because cultures would float off the mesh once submerged in fixative). Explants were transferred carefully (with a spatula) to scin- 
tillation vials containing fresh $4 \% \mathrm{PF}$ and fixed overnight. The next day cocultures were rinsed $4 \times$ in fresh PBS, placed in $1 \%$ BSA/PBS for $3 \mathrm{hr}$, and then incubated overnight at room temperature in a rabbit antibody to tyrosine hydroxylase (TH, 1:1000; Eugene Tech) in PBS. The next day explants were rinsed $3 \times$ in PBS and incubated for $2 \mathrm{hr}$ in an anti-rabbit secondary antibody conjugated to HRP. After three rinses in PBS, endogenous peroxidase activity was blocked with a 1:2 methanol/3\% peroxide solution for $10 \mathrm{~min}$, and the explants were rinsed $3 \times$ in PBS and reacted for peroxidase with $\mathrm{DAB}$ and hydrogen peroxide.

Electron microscopic immunocytochemistry studies of cultured explants. Explants cultured with embryonic VM cells on their surfaces were processed for TH immunocytochemistry, as described above, and further processed for electron microscopy, as previously described (Steindler et al., 1989a, 1990). Transverse sections through the explants were cut on a Reichardt ultramicrotome to facilitate viewing of attached cells in relation to elements within the depths of the cultured explant (coplant). Heavy metal counterstained, as well as unstained, thin sections were viewed under a JEOL JEM 1200 EX electron microscope, and montages were prepared of regions of explants that did or did not exhibit labeled, attached embryonic dopamine neurons.

Cell counts and measures of neurite growth. The center of each explant substrate/E15 VM cell coplant was estimated under the light microscope at low magnification (using a $4 \times$ objective). Refocusing on this center point at $20 \times$, we counted $\mathrm{TH}^{+}$cells within this field (a circular field, 740 $\mu \mathrm{m}$ in diameter) and entered the numbers into a Macintosh IIci computer. Statistical analysis was computed with the aid of Microsoft Excel. A Student's $t$ test was performed on means from control conditions and each experimental condition independently. $\alpha$ values for $t$ [see "critical values of $t$ " (Mendenhall, 1975)] were used to determine the level of statistical significance for each Student's $t$ test. At the same magnification in which cell counts were obtained (i.e., $20 \times$ ), the length of primary neuritic processes (no more than 2 measured from 1 cell) were measured via an optical reticle. In certain coculturing paradigms (i.e., unwounded and $1 \mathrm{hr}$ wounded as well as CS-56 perturbated wounds) the number of cells adhering to the substrate was much too low (i.e., average of $<1.0$ $\mathrm{TH}^{+}$cells per substrate) for statistical analysis of neurite growth. An average of the cell attachment and neurite growth in each culture paradigm was expressed in histogram format, along with statistically significant differences and SEM.

\section{RESULTS}

\section{GFAP, CSPG, and tenascin expression in} striatal wounds

GFAP immunoreactive $(+)$ astrocytes are sparse in $1 \mathrm{~d}$ survival wounds, yet a robust reactive gliosis begins to form during the second to third days after penetrating lesions, as performed here. By the fifth day, a gradient of reactive gliosis can be seen throughout the striatum, with the greatest concentration of reactive $\mathrm{GFAP}^{+}$astrocytes being just around the wound site (Fig. 3A,B). This staining pattern is similar in and around wounds from lesions up to $10 \mathrm{~d}$. Labeling for CSPGs is not apparent in explants from the wounded adult striatum until $3 \mathrm{~d}$ after lesioning, and it becomes most intense $\sim 4-6 \mathrm{~d}$ after lesioning (Fig. 3C). Peak immunostaining with the CS-56 antibody is not so robust as GFAP immunoreactivity, and a somewhat diffuse staining is confined to the wound itself with a dense border around the wound. CSPG immunoreactivity is similar in explants taken from wounds up to $10 \mathrm{~d}$ after a penetrating injury. Tenascin immunoreactivity is not dense until 3-5 d after a penetrating injury, reaching its greatest intensity at the $\sim 6-7 \mathrm{~d}$ (Fig. $3 D$ ). Tenascin protein expression around a lesion seems to be more widespread than CSPG. Immunostaining for the tenascin glycoprotein, for example, can be seen in association with fiber fascicles away from the lesion, whereas CSPG labeling is, for the most part, confined to the primary wound site. The peak tenascin expression was maintained in a similar manner to that seen with anti-GFAP and anti-CSPG (e.g., still present after $10 \mathrm{~d}$ survivals).

\section{GFAP, CS-56, and tenascin expression in striatal wounds after culturing}

GFAP labeling of explants after 1 week in vitro suggested a sustained level in the number of reactive astrocytes (Fig. 4A,B), yet the intensity of wound-associated reactivity seems to subside in explants with longer times in culture. Also, such reactive astrocytes seem to be somewhat distinct in their morphology, e.g., their processes formed what appear to be stubby tangles instead of arbors, as seen in noncultured wounds (compare Figs. 3B, 4B). It also was found that anti-GFAP-treated explants (i.e., using this antibody as a control for the ECM antibody experiments as described below), further processed with a fluorescent secondary antibody alone, exhibited reactivity that was indistinguishable from that seen in explants cultured for 5-6 d. Immunolabeling of matrix molecules from wounds taken after $6 \mathrm{~d}$ survival in vivo and culturing for 5-7 d in vitro showed a less intense distribution within and around the lesion site (when compared with that seen in slices that were not cultured; compare Figs. 3C, 4E). CSPG immunostaining was diffuse within the scar itself, and the more intense border that could be seen surrounding the wound in noncultured preparations was not apparent. Applying a complementary fluorescent-labeled secondary antibody to an antibodyperturbated culture showed a lightly diffuse pattern of staining. Light staining could be seen within the scar but was mostly absent in regions of the explants away from the lesion site (Fig. $4 F$ ). Tenascin expression in explant cultures of $>6 \mathrm{~d}$ wounds was also similar to GFAP and CSPG, in that it seemed to diminish with time in vitro (Fig. $4 C$ ). Immunolabeling for the tenascin glycoprotein seemed to be diffuse and sometimes associated with vascular elements; however, it was persistently dense within a region between the lesion and surrounding tissue structures. Such antitenascin-treated wound explants revealed a similar labeling pattern and intensity (as that described for anti-CSPG) after incubations in a complementary fluorescent secondary antibody (Fig. 4D).

\section{Dopaminergic cell attachment and growth on wounded and unwounded substrates}

$\mathrm{TH}^{+}$(dopamine) cell attachment and process outgrowth varied, depending on the in vivo survival time of the wounded explant (substrate). $\mathrm{TH}^{+}$cells and processes rarely were seen on unwounded or recently wounded (i.e., $1 \mathrm{hr}-1 \mathrm{~d}$ ) substrates (Figs. $5 A-C, 6)$. Small numbers of dopamine cells could be found on 1-2 d striatal wound substrates $(10.75$ cells, \pm 4.2 ; Figs. $5 C, 6)$, and these cells emitted processes that extended an average of $\sim 45$ $\mu \mathrm{m} \pm 6.1$ (Fig. 6). On 3-4 d wounds, many more $\mathrm{TH}^{+} \mathrm{E} 15 \mathrm{VM}$ were attached to the explant, most of which gave rise to thick processes that appeared to be dendrites. On 5-10 d wounds there was a $>15$-fold increase in the number of $\mathrm{TH}^{+}$cells attached to their surfaces over unwounded or $1 \mathrm{hr}-1 \mathrm{~d}$ wounded explant substrata (Fig. 5D) $(231 \pm 18.8$ attached cells, Fig. 6). Very few of the cells, however, seemed to extend long neurite processes, with some cells seeming to have somatic protuberances that appeared to be aborted dendrites (Fig. 5D, inset).

\section{Ultrastructural observations of embryonic cells on wound explants indicate a preservation of astroglial- dopamine neuron cell and molecular constituents}

Immunoelectronmicroscopic studies of embryonic cells plated on the surfaces of wounded striatal explants revealed labeled cells that most likely represent young $\mathrm{TH}^{+}$dopamine neurons (Fig. 7). These cells were consistently one type: small round cells $(\sim 7-9$ 

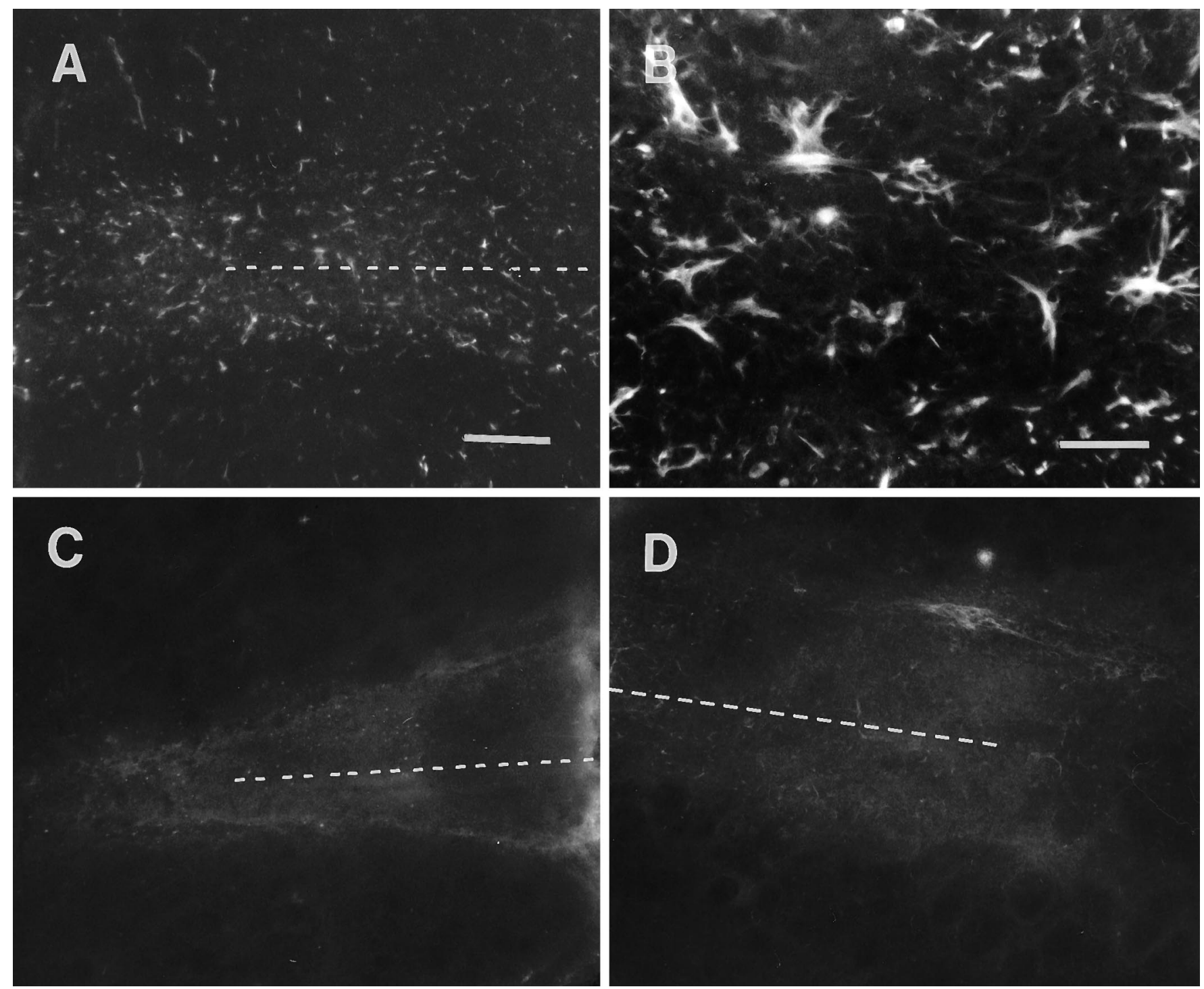

Figure 3. Immunostaining of striatal wounds taken from an adult mouse after $5 \mathrm{~d}$ survival in vivo. $A, B$, GFAP immunoreactivity can be seen throughout the wound (dotted line) and most of the surrounding parenchyma. The wound itself appears most intense, with a decreasing number of reactive astrocytes in surrounding penumbral regions. $B$, Higher magnification of cells shown in $A$ reveals astrocyte somata and processes that are characteristic astroglial scar cells. $C$, CSPG immunoreactivity is confined mostly to the wound area itself (dotted line). Note a thin line (boundary) of particularly intense reactivity for such proteoglycans at the interface between the wound and the surrounding parenchyma. $D$, Tenascin immunoreactivity shows much the same distribution as $\mathrm{GFAP}^{+}$cells. A particularly dense concentration of the glycoprotein can be seen in a diffuse as well fibrous pattern within the wound (dotted line), whereas diffuse staining is widespread in unlesioned portions of the explant (e.g., diffuse staining associated with unencumbered fiber fascicles). Scale bars: for $A, C, D$ (shown in $A$ ), $200 \mu \mathrm{m}$; in $B, 50 \mu \mathrm{m}$.

$\mu \mathrm{m}$ in short diameter) with large nuclei and scant cytoplasm. The immunolabeling was cytoplasmic, having labeled processes, we sometimes observed, closely associated with underlying cells of the explant that possessed attributes of astrocytes (e.g., cells that have rough endoplasmic reticulum with distended cisternae and that also have large, irregularly shaped nuclei with dense chromatin). Some of the cells on the surface of the explants that never exhibited immunolabeling for $\mathrm{TH}$ were presumed to be glial cells (see Fig. $7 A$, which shows a putative oligodendrocyte based on size, electron density, and dense nuclear chromatin pattern). In addition to many vacuolated somata and processes of dying neurons, there was one predominant cell type that appeared astrocytic, most likely representing the $\mathrm{GFAP}^{+}$reactive astrocytes observed at the light microscopic level (Figs. 3, 4). Small dark cells, presumed to be microglia or macrophages, were seen occa- sionally in close proximity to or engulfing vacuolated cells and processes within the explants (Fig. $7 A$ ).

\section{Dopaminergic cell attachment and growth on antibody-treated wound substrates}

Cell counts from cocultures of embryonic neurons and unwounded or recently wounded substrates were considered to be too low to detect any potential differences associated with antibody perturbations. Explants derived from longer in vivo survival times had many more attached cells (Fig. 5D) and were, therefore, used to study the potential effects of particular antibodies and immunoglobulins on cell attachment and process growth on wound substrates. When wounds ( $>6-\mathrm{d}$ in vivo survival) were preincubated in anti-CSPG, CS-56, before coculturing with embryonic VM neurons, virtually no $\mathrm{TH}^{+}$neurons attached to the 

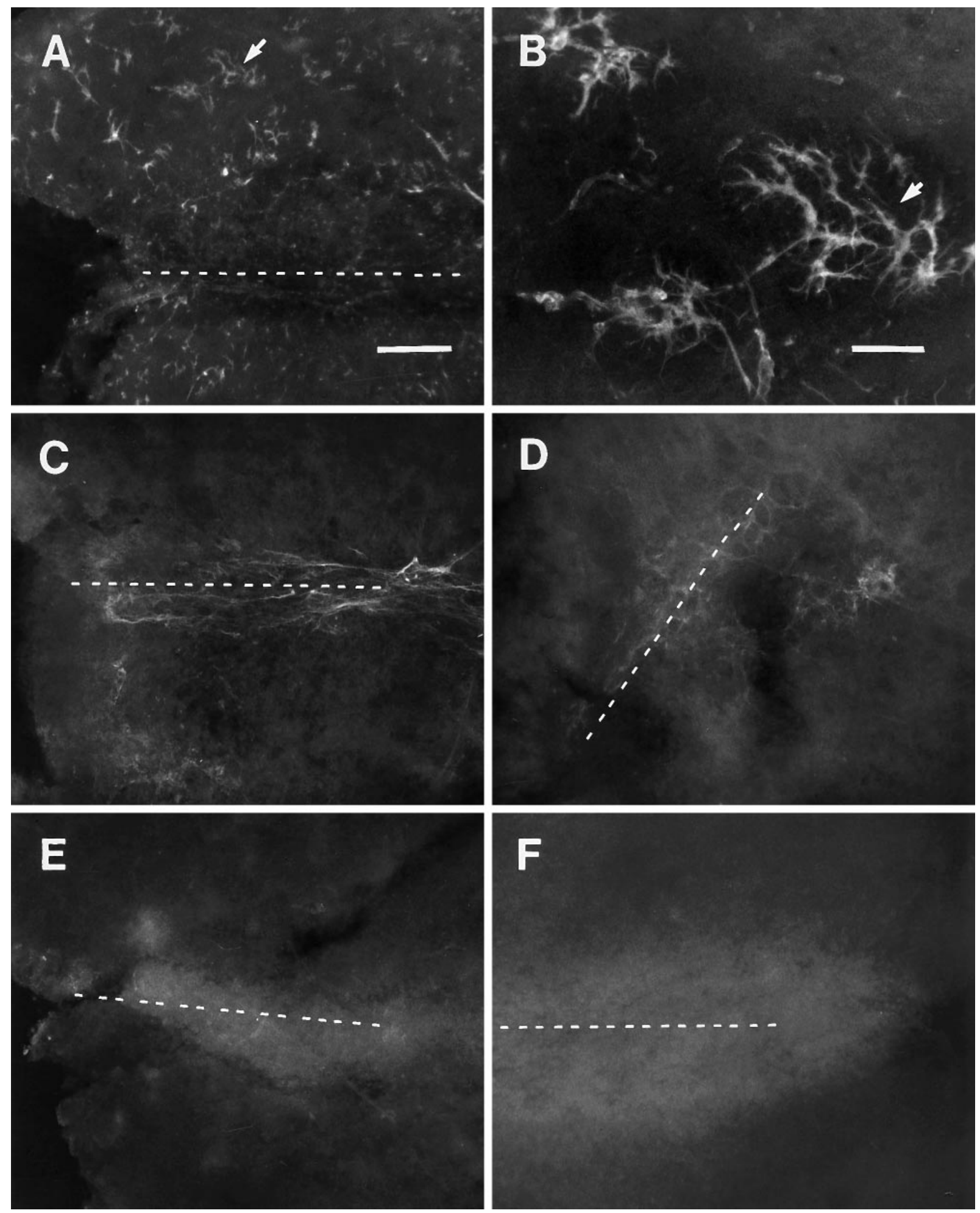

Figure 4. Nontreated and antibody-treated explants taken from wounds after $6 \mathrm{~d}$ survival in vivo, cultured for $6 \mathrm{~d}$, and processed for GFAP, tenascin, and CSPG immunoreactivity. A, B, GFAP immunoreactivity in and around a $6 \mathrm{~d}$ striatal scar (dotted line) after $6 \mathrm{~d}$ in vitro. These reactive astrocytes are labeled more faintly than those on wounds processed immediately after extraction. Anti-GFAP-perturbated $6 \mathrm{~d}$ wounds show very light or indiscernible reactivity when processed with a complementary fluorescence-tagged secondary antibody to GFAP. Note (in $B$ ) GFAP ${ }^{+}$cells have distinct morphologies, e.g., exhibiting many swollen, irregular processes. $C$, Tenascin immunoreactivity is maintained in the $6 \mathrm{~d}$ striatal wound (dotted line) after $6 \mathrm{~d}$ in vitro however, only diffuse labeling can be seen in surrounding areas of the explant. Tenascin immunoreactivity seems to be fibrous within the wound, with light extracellular staining in adjacent areas. $D$, Note a similar, although lighter, pattern of staining in perturbated cultures (with the polyclonal tenascin antibody) processed with secondary antibody alone. Fibrous processes within the wound region (dotted line) are surrounded by light diffuse reactivity in adjacent areas. $E$, Light CSPG immunoreactivity is confined to the primary wound site of a $6 \mathrm{~d}$ striatal wound (dotted line) after $6 \mathrm{~d}$ in vitro, without a notably intense region at the border of the lesioned and unlesioned portion of such explants. $F$, A similar pattern of immunostaining can be seen on CS-56 antibody-treated cultures after the same culture period. Scale bars: for $A, C-F$ (shown in $A$ ), $200 \mu \mathrm{m}$; in $B, 50 \mu \mathrm{m}$. 


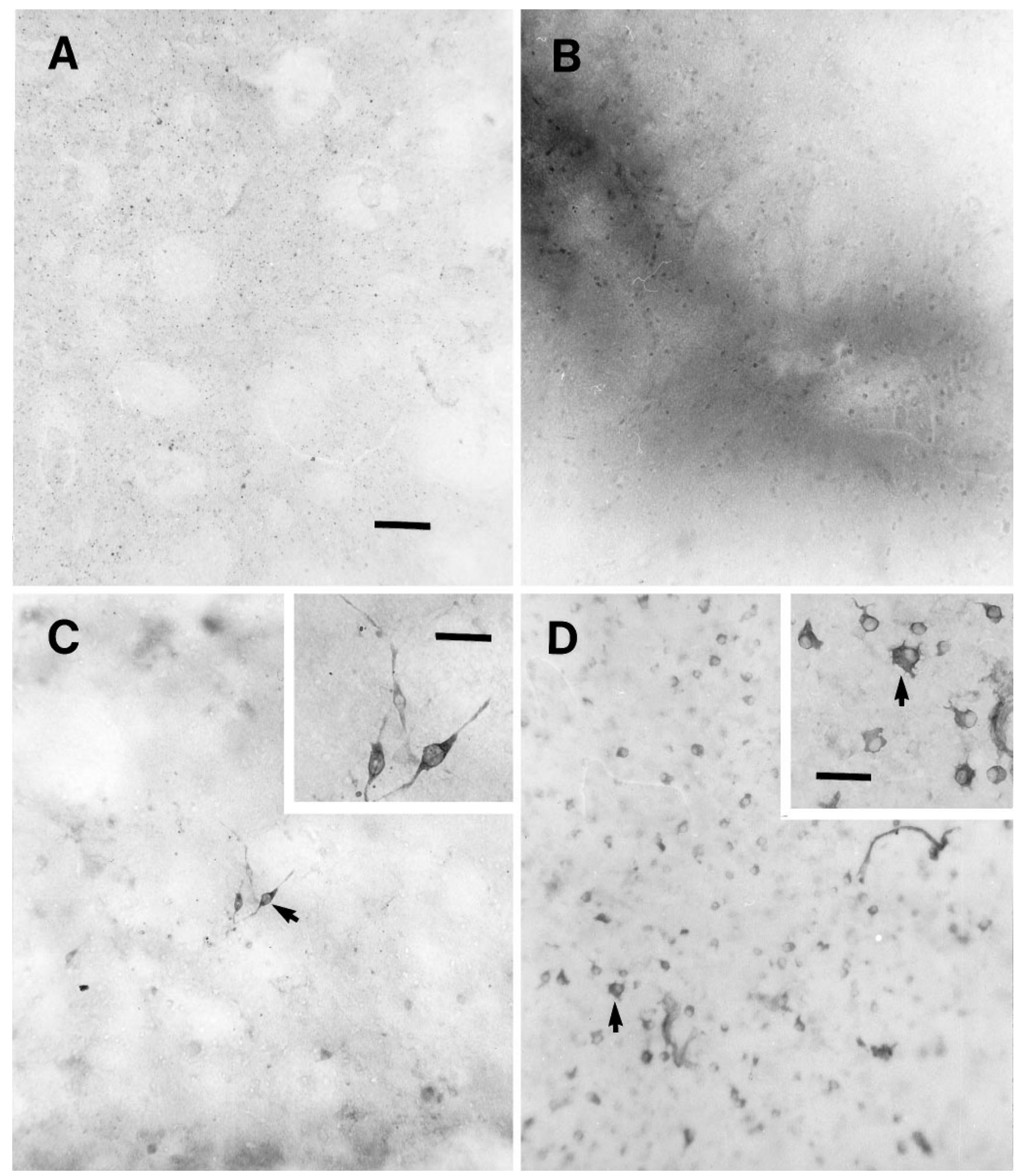

Figure 5. Photomicrographs of $\mathrm{TH}^{+} \mathrm{VM}$ cell attachment on explants from wounds taken after different in vivo survival times. All explants were used as a substrate for dissociated E15 cells and processed for TH immunocytochemistry after $6 \mathrm{~d}$ in vitro. A, On unwounded (control) explants, note the absence of dopamine cells throughout the explants, but punctate immunolabeling is apparent, which most likely represents degenerating nigrostriatal dopaminergic axons of the host explant. $B$, Virtually no $\mathrm{TH}^{+} \mathrm{E} 15 \mathrm{VM}$ cells are attached to a $1 \mathrm{hr}$ wound explant processed identically to the control shown in $A$. Note the densely labeled wound region, most likely a result of endogenous peroxidase activity of vascular-related cells. $C$, On an explant taken from a striatal wound $2 \mathrm{~d}$ after lesioning, there is moderate $\mathrm{TH}$ cell attachment and neurite growth. $C$, Inset, Note how the few adherent $\mathrm{TH}^{+}$cells on these wound substrates are bipolar. $D, \mathrm{TH}^{+}$cell attachment is greatly enhanced on a striatal wound taken $6 \mathrm{~d}$ after lesioning and used as a substrate for E15 VM cells. Note, however, that these cells seem to give rise to few, if any, processes (inset). Scale bars: for $A-D$ ( $\operatorname{shown}$ in $A$ ), $50 \mu \mathrm{m}$; in $C$ and $D$ insets, $25 \mu \mathrm{m}$. 

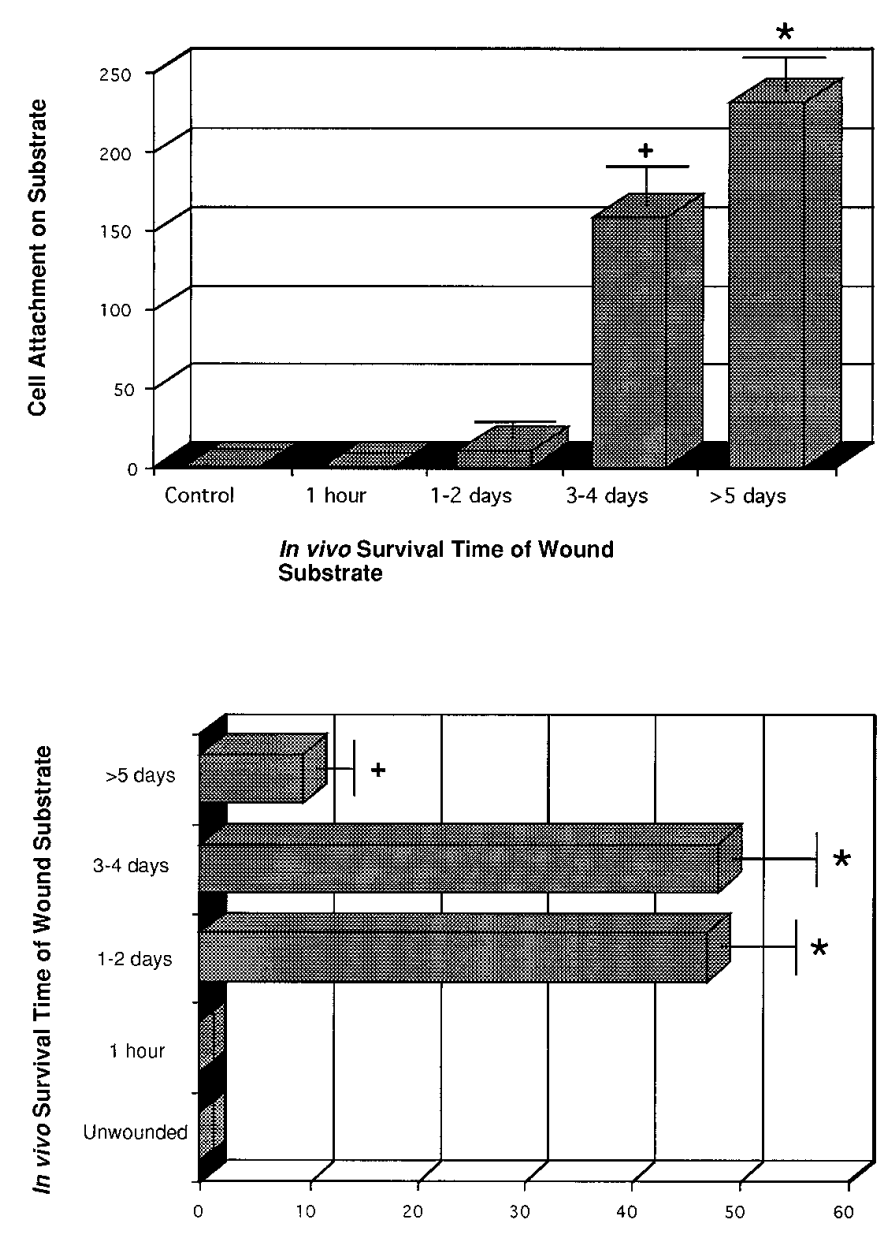

Neuritic Growth (in $\mu \mathrm{m}$ ) from Cells Attached to Substrate

Figure 6. Histograms showing the average TH cell attachment (top graph) and process outgrowth (bottom graph) on adult striatal wounds used as substrates after various in vivo survival times. Substrates from the unwounded (control, $n=14$ ) or $1 \mathrm{hr}$ wounded $(n=7)$ adult mouse striatum support little or no attachment for E15 $\mathrm{TH}^{+}$cells. Some $\mathrm{TH}^{+}$ cells consistently attach to substrates made from striatal wounds left $1-2 \mathrm{~d}$ in vivo $(n=5)$ before coculturing with dissociated E15 VM cells; a significant increase in $\mathrm{TH}^{+}$cell attachment was apparent on striatal wounds used as substrates after $3-4 \mathrm{~d}$ survival in vivo $(n=4)$. This increase in cell attachment peaked on substrates obtained from 5-10 d striatal wounds. $(+)$ and $(*)$ denote statistically significant differences from the control group, with $p>0.025$ and $p>0.005$, respectively.

substrate (Figs. $8 C, 9$ ). This absence of cells was even more striking than that seen with unwounded or recently wounded substrata, described above, where at least occasional labeled, attached cells were observed. When substrates were exposed to anti-tenascin antibody ( $n=6$ for the polyclonal antibody; $n=2$ for the fabs), significantly fewer $\mathrm{TH}^{+}$cells attached to the explant (in comparison with the untreated 6-10 d substrates, Figs. 5D, 8A, 9; e.g., an average of $91.2 \pm 16.2$ cells with anti-tenascin vs $234 \pm$ 17.4 cells on the control untreated $6 \mathrm{~d}$ wound), and these cells extended thick dendritic-like arbors as well as thin (axon-like) varicose processes (Fig. $8 D$ ). These cells were similar in appearance to those attaching to wounds taken before the upregulation of the tenascin glycoprotein (compare Figs. 5C, 8D). Processes grown on anti-tenascin-treated substrates were significantly longer than those seen on wounds of the same survival time that were not exposed to anti-tenascin (Fig. 9).
When antibodies to GFAP or RC-2 (an IgM antibody to radial glial and immature astrocyte cytoplasmic elements), as well as normal rabbit serum or mouse IgM (173 and 198 cells attached, not graphed in Fig. 9 because of the $n=2$ ) were used at the same concentrations and under similar conditions as in the anti-CSPG and anti-tenascin perturbation experiments, there was no significant effect on cell attachment or neuritic growth, as compared with adult or postnatal day 6 wounded (6-d survival) striata that were not exposed to any of the antibodies, serum, or immunoglobulin (Fig. 9). Other control experiments that used preadsorption of the CS-56 antibody with chondroitin sulfate $\mathrm{C}$ yielded dopamine cell attachment on wound explants similar to untreated cocultures.

\section{DISCUSSION}

The findings presented here show temporal and spatial differences between the expression of proteoglycans and tenascin in and around wounds of the adult mouse striatum. Coinciding with the peak upregulation of CSPG and tenascin in the adult striatum (3-4 and 5-6 d after lesioning, respectively) was a variability in embryonic dopaminergic cell attachment and process outgrowth in cocultures of VM cells on lesioned striatal explants. In this study, we only used $\mathrm{TH}$ as a marker of attached neurons, and it is certainly possible that nondopaminergic cells may also attach and survive the various conditions described here. More $\mathrm{TH}^{+}$cells attach to wounds that survived in vivo $>3 \mathrm{~d}$, whereas neurite growth is reduced with longer survival periods (e.g., $>5 \mathrm{~d}$ ). The finding that more cells attach with less neurite growth in the longer postlesion survival explant suggests that the early injury response might be composed partially of growth factors that support neuritic growth (for review, see Brodkey et al., 1993), whereas the later response is dominated by factors (e.g., ECM) that support cell attachment but have negative effects on neurite growth.

In the coculturing paradigm used here, we have shown that striatal wound explants support more dopamine cell attachment than unlesioned substrates. Perturbation of wound substrates with the CS-56 antibody, which presumably binds to chondroitin sulfate moieties of a variety of wound-associated proteoglycans (Avnur and Geiger, 1984; Fichard et al., 1991; Pindzola et al., 1993), resulted in virtually no dopaminergic cell attachment to explants, regardless of the survival time; the subsequent increase in cell adhesion on substrates from longer survival times (i.e., corresponding with the onset of tenascin expression) suggests that ECM molecules, and particularly glial-associated ECM, may work in concert to increase cell attachment. Interestingly, application of tenascin antibodies reduces cell attachment (albeit to a lesser degree than CSPG), but it also facilitates process outgrowth. One must be extremely cautious when interpreting antibody perturbation data, because it is difficult to rule out such phenomena as steric hindrance that may be involved in the observed effects. The use of different antibodies to two different ECM molecules led to different results in the present paradigm (e.g., anti-tenascin was not as effective as CS-56 in inhibiting dopamine cell attachment), suggesting that the different ECM antibodies studied here could be considered as controls for each other. Nonetheless, we do not understand how these antibodies may interfere with the cellular events assayed here, and we have no information on the sites of the tenascin protein that may be recognized by the tenascin antibodies used in this study nor how the binding of these sites may lead to a specific inhibition or interference with the binding of other molecules that also may affect cell attachment and 

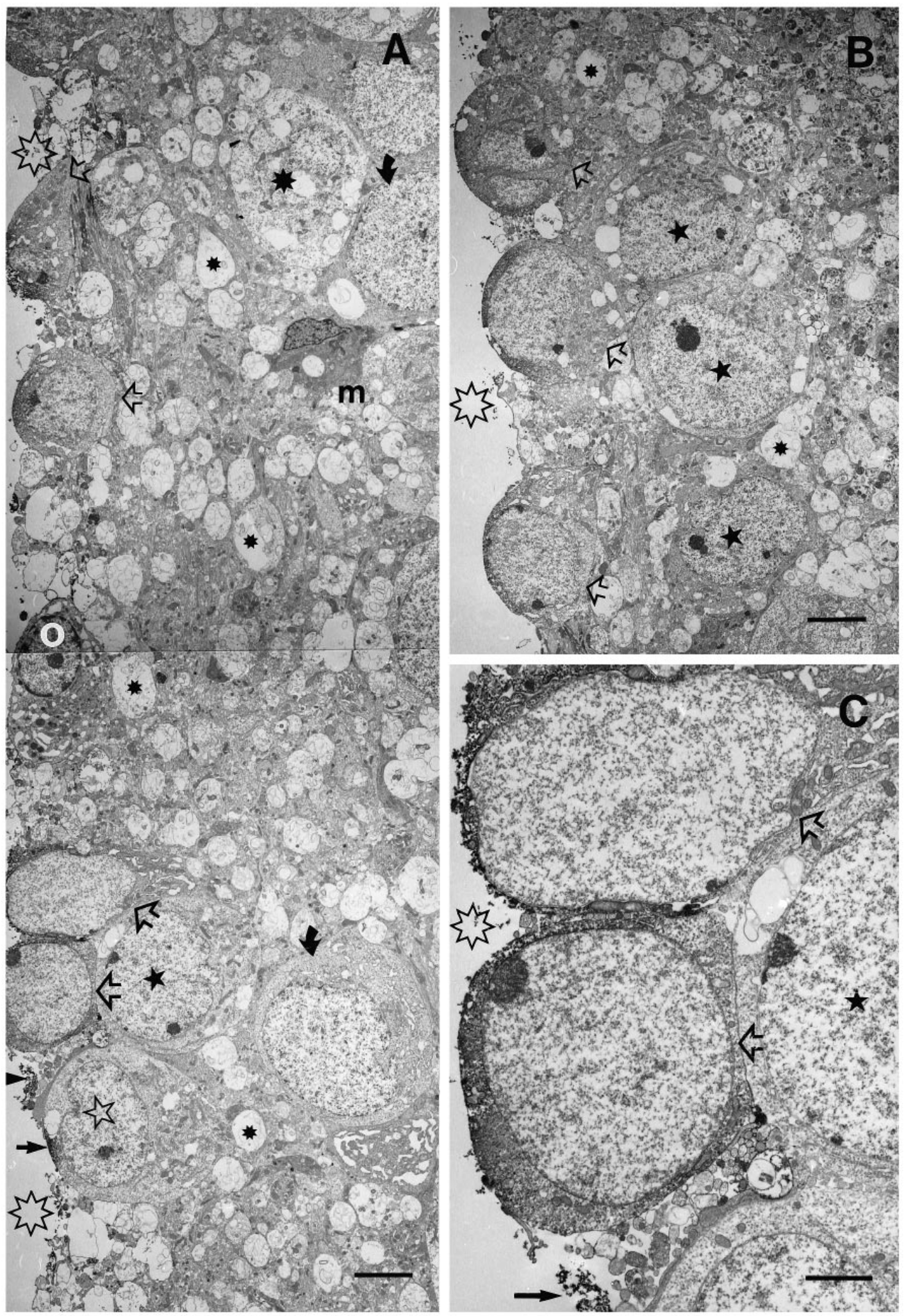

Figure 7. Electron microscopic immunocytochemistry of a $6 \mathrm{~d}$ survival striatal wound, $6 \mathrm{~d}$ in vitro, with E15 VM neurons attached. TH ${ }^{+}$cells (open arrows) are visible on the surface of the explant (montage in $A$ ), in $B$, and at higher magnification in $C$. Open asterisks mark the outside surface of the explant. $A$, In addition to $\mathrm{TH}^{+}$cells, small TH-labeled processes (filled straight arrows) can be seen in close proximity to astrocytes (open star). The filled star in the nucleus of an astrocyte, underneath two putative dopamine cells, is seen in higher magnification in $C$ (again, filled star in nucleus). The filled asterisks are in degenerating neurites and degenerating neuronal somata (large filled asterisk in $A$ ). Curved filled arrows point to surviving astrocytes deep within the explant. $O$, Putative oligodendrocyte; $m$, putative macrophage or microglial cell. $B$, A different region of the striatal scar explant showing three $\mathrm{TH}^{+}$cells (open arrows) in close association with three astrocytes (filled stars). $C$, A higher magnification micrograph showing details of the neuropil that lacks host neurons, neurites, and synapses, but glia, matrix, and plated $\mathrm{TH}^{+}$cells (and their processes, straight filled arrow) are visible. Scale bars: in $A$, $B, 5 \mu \mathrm{m}$; in $C, 2 \mu \mathrm{m}$. 

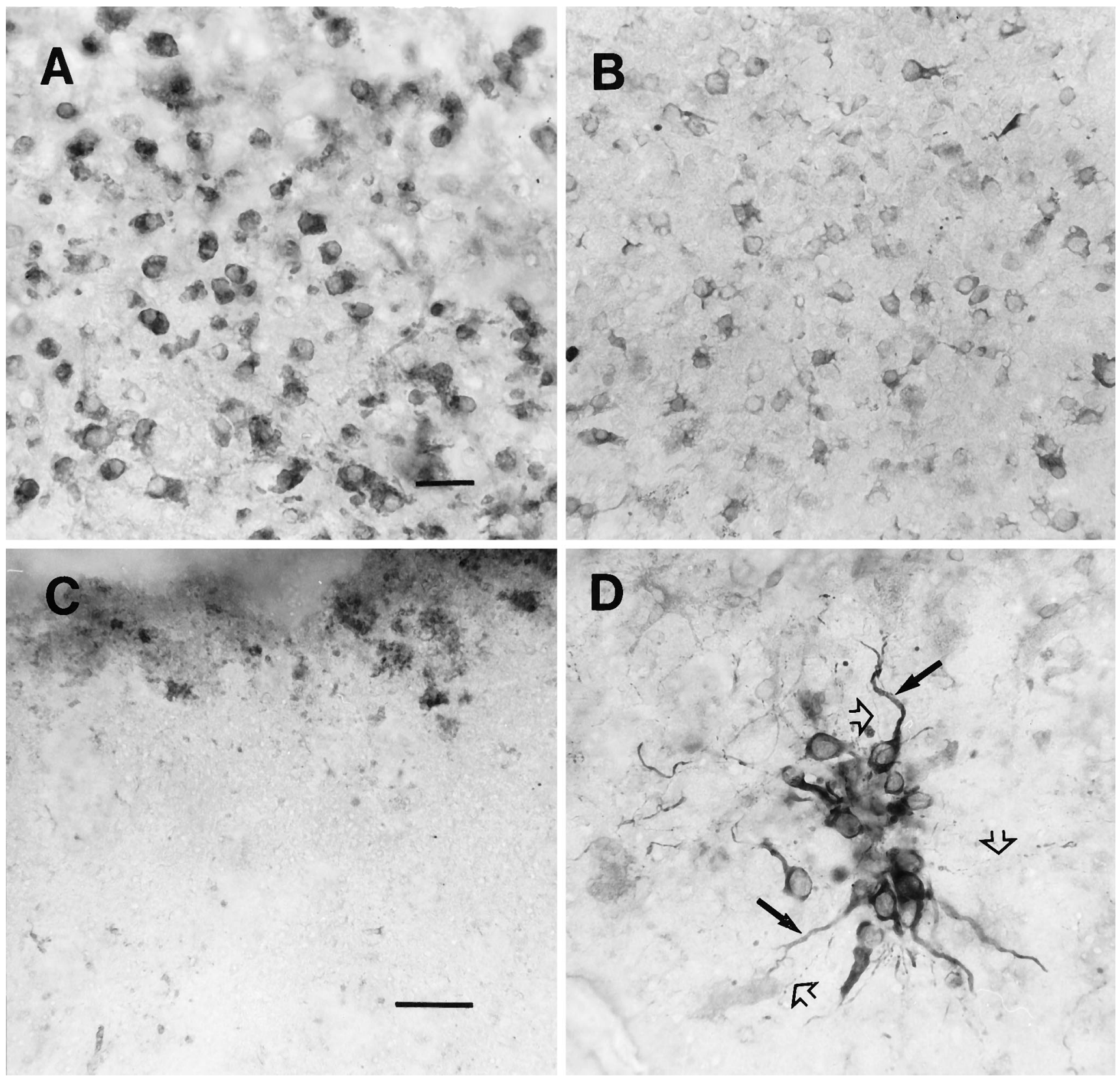

Figure 8. The effects of antibody treatment on E15 TH cell attachment and process outgrowth on substrates obtained from striatal wounds of $>5 \mathrm{~d}$ survival (usually $6 \mathrm{~d}$ ) in vivo. VM cells were allowed to attach and remain on substrates for $6 \mathrm{~d}$ in vitro. A, Note numerous $\mathrm{TH}^{+}$cells that attach to the untreated (control, no antibody treatment) substrate; however, the cells exhibit distinctive morphologies (compare with Fig. 5D). B, A similar pattern of TH cell attachment and process outgrowth can be seen on wounds perturbated with the GFAP antibody. $C$, On CS-56 perturbated wound substrates, no TH cells are attached to the substrate. $D$, Alternatively, a tenascin antibody-perturbated substrate supports less cell attachment (compared with controls or GFAP-perturbated substrates, $A$ and $B$ ), yet cells that do attach to the substrate elaborate numerous thick (closed arrows) as well as thin varicose (open arrows) processes that are presumably dendrites and axons, respectively. The dense labeling in this figure represents numerous TH-immunolabeled processes, as well as nonspecific background labeling associated with the wound site (top of figure). Scale bars: for $A, B$ (shown in $A$ ), $50 \mu$ m; for $C, D$ (shown in $C$ ), $60 \mu \mathrm{m}$.

neurite growth-related events. The CS-56 mAb, on the other hand, has been used as a function-blocking antibody in a study of CSPGs involved in the avoidance of epidermis by dorsal root ganglia fibers (Fichard et al., 1991), in which it was shown that this avoidance could be abolished when cultures were grown in the presence of CS-56. Perturbation of any wound substrate with the CS-56 antibody (which supposedly recognizes both chondroitin-6 and chondroitin-4 glycosaminoglycan moieties of potentially many CSPGs) resulted in virtually no $\mathrm{TH}^{+}$cell attachment. The actions are, therefore, presumed to relate to the sugar moieties, but the core proteins (up to 25 have been reported in the rodent nervous system; Herndon and Lander, 1990) and the GAG chains may give rise to diverse biological actions (Oohira et al., 1988; Iijima et al., 1991). In light of the observations made here on CSPGs actions on embryonic VM dopamine cell attachment and neurite growth, it seems that they can support neural cell attachment on wound explant substrates; unfortunately, their actions on neurite growth were not amenable to analyses in the current bioassay 


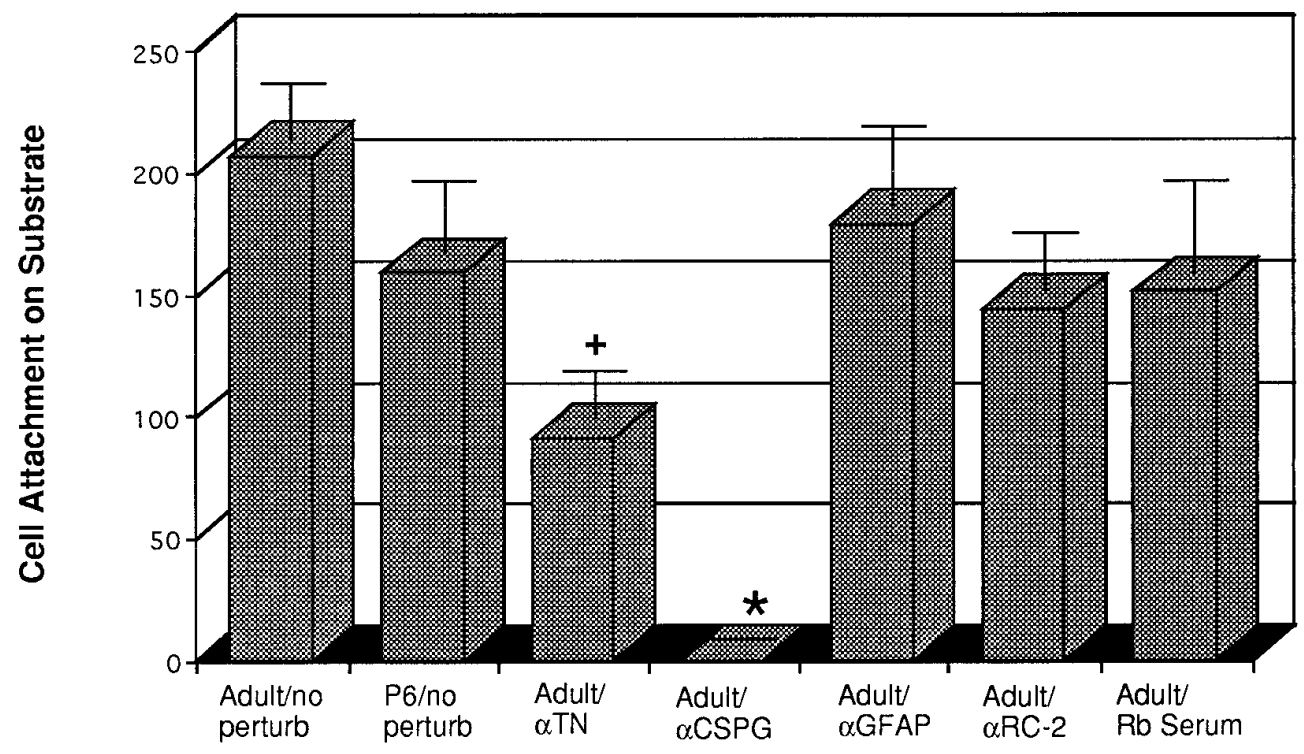

Conditions of 6 Day Striatal Wounds

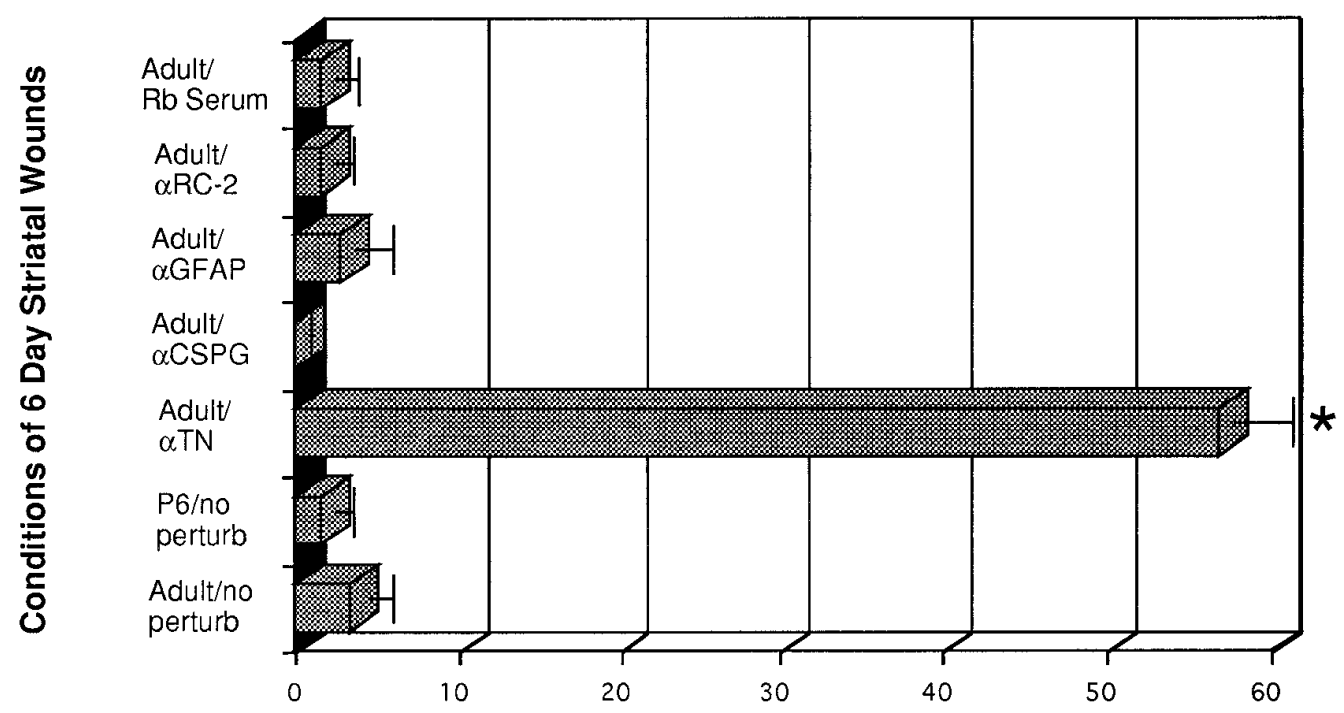

Neuritic Growth (in $\mu \mathrm{m}$ ) from Cells Attached to Substrate

Figure 9. Histograms showing $\mathrm{TH}^{+}$cell attachment (top graph) and process outgrowth (bottom graph) on $>5 \mathrm{~d}$ wounds treated with antibodies or serum. Note the dramatic reduction in $\mathrm{TH}^{+}$cell attachment on both CS-56 and anti-tenascin-treated cultures, as compared with untreated adult cocultures (Adult/no perturb), anti-GFAP, anti-RC-2, and rabbit serum-exposed explants that exhibit no statistically significant differences from the adult or postnatal day 6 untreated cultures $(n=8$ for the adult/no perturb; $n=3$ for anti-GFAP; $n=6$ for the anti-tenascin experiments). Reduced cell attachment on anti-tenascin-treated cocultures was accompanied by an increase in neurite outgrowth. Wound substrates from the P6 striatum maintain a similar level of cell attachment and process outgrowth of E15 VM cells, as do their adult counterparts. $(+)$ and $\left(^{*}\right)$ denote statistically significant differences from adult/nonperturbated (nontreated, control) conditions, with $p>0.025$ and $p>0.005$, respectively.

because of the profound negative effect of the CS-56 antibody on cell attachment to the wound substrates. Certainly antibodies to other ECM molecules should be tested in this paradigm, because the control antibodies that were used here were chosen on the basis of their species or immunoglobulin specificity as well as their inability to recognize ECM or surface proteins (e.g., anti-GFAP and RC-2 that bind cytoskeletal components) that likewise could affect the cell and molecular interactions assayed here. 
Wounding of the adult CNS results in an astrogliosis (or glial scar) (Windle et al., 1952; Bignami and Dahl, 1976; Reier et al., 1983; Eng, 1988; Reier and Houle, 1988; Norenberg, 1994). The glial scar is demonstrated readily by using GFAP immunocytochemistry (Bignami and Dahl, 1976; Eng, 1988) within 1-2 d after injury. Reactive astrocytes upregulate their expressions of extracellular matrix proteins, which are likewise associated with an immature form of these cells (Pixley and de Vellis, 1984; McKeon et al., 1991; Laywell et al., 1992; Pindzola et al., 1993). The upregulation of astrocytic ECM supposedly results from the release of cytokines, growth, and other factors released from vascular elements or dying neurons (Pearson et al., 1988; Logan et al., 1992; Brodkey et al., 1993; Meiners et al., 1993). The enhanced expression of two of these ECM constituents, CSPG and tenascin, seems to be associated with gliosis and peaks $\sim 3-4$ and 5-6 d, respectively, after a penetrating injury. The significance of these responses relates to their potentially crucial effects on plasticity and regeneration of the adult CNS (reviewed in Brodkey et al., 1993; Schwab et al., 1993; Steindler, 1993).

The preservation of a reactive astrogliosis in culture conditions described here is certainly not the same as that seen after injury in vivo; nonetheless, putative growth-associated molecules like CSPG and tenascin are expressed in lesions in both paradigms. The wound itself remains reactive, perhaps because of the in vivo exposure of glia to vascular-derived factors that affect ECM expression as described above; the explant sectioning process seems not to generate such reactive glia because unwounded explants did not support TH cell attachment. Traditionally, reactive astrocytes and many of their associated glycoconjugates are thought to inhibit neurite outgrowth and thus play a role in failed regeneration of the adult CNS. At least some biological actions of tenascin seem to be altered in the presence of anti-tenascin antibody in our culture paradigm. A recent study also has used one of these antibodies, in a completely different paradigm, to alter the attachment of PC12 and embryonic VM cells to cryocultures of wounds (Laywell et al., 1996). Anti-tenascin antibodies also have been used in other in vitro bioassays to affect the migration, attachment, and neurite growth properties of a variety of cells (Husmann et al., 1992; Langenfeld-Oster et al., 1994). In vitro bioassays of proteoglycans have revealed predominantly inhibitory actions on growing neurites when presented in high concentrations, in different combinations (e.g., chondroitin and keratan sulfate), and when offered as a choice with laminin or polycations (Snow et al., 1990a; Snow and Letourneau, 1992). It seems that a dense concentration of ECM molecules like tenascin and CSPGs, as described in boundaries around developing functional units in vivo (Steindler et al., 1989a; Crossin et al., 1990; Oakley and Tosney, 1991), or in culture bioassays where a sharp boundary with another substrate (e.g., laminin) is produced, is predominantly repulsive to neuronal cell bodies or growing neurites (Faissner and Kruse, 1990; Lochter et al., 1991; Taylor et al., 1993; Krull et al., 1994; Faissner and Steindler, 1995). Again, in the coculturing paradigm used here, we found that striatal wound explants, which exhibit immunostaining for tenascin and CSPGs, support more dopamine cell attachment than unlesioned substrates. These effects of wound-associated molecules on dopamine neuron attachment are somewhat similar to those described by David et al. (1990) who showed, using cryocultures of lesioned optic nerve, that an area just around an optic nerve lesion is distinctly supportive for cell attachment. CSPGs and tenascin may have extremely complex actions (Faissner and Steindler, 1995), and they have been described under certain circumstances as being adhesive or antiadhesive proteins that might contribute to cell (and process) movement via the making or breaking of cell-substrate contacts. Our findings should not lead one to conclude that cell attachment, or the lack thereof, after antibody treatment is revealing the actions of these molecules, in and of themselves, in inhibiting attachment or neurite outgrowth. In the lesion and culture conditions created in our study, cell adhesion may become too great or too weak, and either condition at an extreme actually may be detrimental to neurite outgrowth in the presence of certain ECM molecules.

Wounds of the adult CNS may have more complex actions on neurons than previously considered, and this may be relevant to the transplantation of embryonic dopamine cells to the adult striatum that is used in cell replacement therapies for Parkinson's disease. The ECM molecule composition of the graft versus host may be different (Gates et al., 1996), and previous studies of nerve grafts to the adult brain [e.g., optic nerve to the cerebellum, see Zwimpfer et al. (1992) and sciatic nerve to the diencephalon, see Zang et al. (1995)] have shown that matrix molecules like tenascin not only are expressed strongly by grafted cells but also are expressed constitutively by distinct regions of the host CNS. Grafted retinal axons will invade the adult cerebellar granule cell layer (Zwimpfer et al., 1992), which expresses little tenascin, but completely avoid the tenascin-rich molecular layer, in a manner that suggests inhibition of graft fiber ingrowth where there is a dense host tenascin expression.

It is possible that tenascin works in conjunction with CSPGs to facilitate cell adhesion (tenascin and an associated proteoglycan are often coexpressed; see Hoffman and Edelman, 1987; Hoffman et al., 1988). Tenascin and CSPGs are coexpressed in boundaries during CNS development (Steindler et al., 1990), and we have shown recently that both tenascin and CSPG are expressed in the embryonic VM at a time when dopaminergic cells are migrating to and growing processes within this region (i.e., E14-E18; Gates et al., 1996). Recent studies (Bicknese et al., 1994; McAdams and McLoon, 1995) have shown that CSPG is densely expressed in a region of the developing cortical subplate through which large numbers of thalamocortical fibers travel. A CSPG-containing proteoglycan termed DSD-1-PG (Faissner et al., 1994) is present in developmental boundaries (Steindler et al., 1990), but it has been reported to give rise to neurite growth-promoting activities (Faissner et al., 1994) (for a review of different proteoglycans and their actions, see Herndon and Lander, 1990; Faissner et al., 1994; Letourneau et al., 1994; Thomas and Steindler, 1995). It might also be suggested, from our antibody blocking studies, that CSPGs are more essential than tenascin in this collaborative effect on dopamine cell adhesion, with tenascin only augmenting such actions. Studies on a tenascin-deficient mouse have failed to uncover obvious neural phenotypes, perhaps because of the expression of backup boundary molecules (Steindler et al., 1995), yet subtle disturbances in morphogenesis and wound healing still may exist in this mutant. Finally, recent studies by Geller and colleagues (Grierson et al., 1990; Meiners et al., 1995) have described two morphologically distinct sets of cultured astrocytes with differential effects on neurons. "Rocky" astrocytes are rich in both chondroitin-6-sulfate proteoglycans and tenascin and seem to be repulsive for certain embryonic neurons; "flat" astrocytes, which do not express these CSPGs (but they do express small amounts of tenascin), seem to support neurons and neurite growth (Grierson et al., 1990; Meiners et al., 1995).

In conclusion, previous in vivo studies of substantia nigra grafts to the neostriatum have revealed the presence of ECM within and around such grafts (Gates et al., 1996), and the present in vitro 
observations of an increase in young dopamine neuron affinity for an ECM-rich striatal wound substrate may offer insights into cell and molecular interactions that affect the survival and integration of dopamine cell grafts.

\section{REFERENCES}

Aguayo L, David S, Bray G (1981) Influences of glial environment on the elongation of axons after injury: transplantation studies in adult rodents. J Exp Biol 231-240.

Aukhil I, Joshi P, Yan Y, Erickson H (1993) Cell- and heparin-binding domains of the hexabrachion arm identified by tenascin expression proteins. J Biol Chem 268:2542-2553.

Avnur Z, Geiger B (1984) Immunocytochemical localization of native chondroitin sulfate in tissues and cultured cells using specific monoclonal antibody. Cell 38:811-822.

Bicknese AR, Sheppard AM, O'Leary DDM, Pearlman AL (1994) Thalamocortical axons extend along a chondroitin sulfate proteoglycanenriched pathway coincident with the neocortical subplate and distinct from the efferent path. J Neurosci 14:3500-3510.

Bignami A, Dahl D (1974) The development of Bergmann glia in mutant mice with cerebellar malformations: reeler, staggerer, and weaver. Immunofluorescence study with antibodies to glial fibrillary acidic protein. J Comp Neurol 155:219-230.

Bignami A, Dahl D (1976) The astroglial response to stabbing: immunofluorescence studies with antibodies to astrocyte-specific protein (GFA) in mammalian and submammalian vertebrates. Neuropathol Appl Neurobiol 2:99-110.

Bjorklund A, Stenevi U, Schmidt R, Dunnett S, Gage F (1983) Intracerebral grafting of neuronal cell suspensions. I. Introduction and general methods of preparation. Acta Physiol Scand Suppl 522:1-7.

Brodkey JA, Gates MA, Laywell ED, Steindler DA (1993) The complex nature of interactive neuroregeneration-related molecules. Exp Neurol 123:251-270.

Brodkey JA, Laywell ED, O’Brien TF, Faissner A, Stefannson K, Dorries U, Schachner M, Steindler DA (1995) Focal brain injury results in the upregulation of a developmentally regulated extracellular matrix protein. J Neurosurg 82:106-112.

Chamak B, Prochiantz A (1989) Influence of extracellular matrix proteins on the expression of neuronal polarity. Development (Camb) 106:483-491.

Chamak B, Fellous A, Glowinski J, Prochiantz A (1987) MAP2 expression and neuritic outgrowth and branching are coregulated through region-specific neuro-astroglial interactions. J Neurosci 7:3163-3170.

Chiquet-Ehrismann R (1990) What distinguishes tenascin from fibronectin? FASEB J 4:2598-2604.

Crossin K, Hoffman S, Grumet M, Thiery J-P, Edelman G (1986) Siterestricted expression of cytotactin during development of the chick embryo. J Cell Biol 102:1917-1930.

Crossin KL, Prieto AL, Hoffman S, Jones FS, Freidlander DR (1990) Expression of adhesion molecules and the establishment of boundaries during embryonic and neural development. Exp Neurol 109:6-18.

David S, Aguayo AJ (1981) Axonal elongation into peripheral nervous system "bridges" after central nervous system injury in adult rats. Science 214:931-933.

David S, Bouchard C, Tsata O, Giftochristos N (1990) Macrophages can modify the nonpermissive nature of the adult mammalian nervous system. Neuron 5:463-469.

Denis-Donini S, Glowinski J, Prochiantz A (1984) Glial heterogeneity may define the three-dimensional shape of mouse mesencephalic dopaminergic neurons. Nature 307:641-643.

Dorries U, Taylor J, Xiao Z, Lochter A, Montag D, Schachner M (1996) Distinct effects of recombinant tenascin-C domains on neuronal cell adhesion, growth cone guidance, and neuronal polarity. J Neurosci Res 43:420-438.

Eddelston M, Mucke L (1993) Molecular profile of reactive astrocytes: implications for their role in neurologic disease. Neuroscience 54:15-36.

Edwards MA, Yamamoto M, Caviness Jr VS (1990) Organization of radial glia and related cells in the developing murine CNS. An analysis based upon a new monoclonal antibody marker. Neuroscience 36:121-144.

Eng LF (1988) Regulation of glial intermediate filaments in astrogliosis. In: The biochemical pathology of astrocytes (Norenberg MD, Hertz L, Schousboe A, eds), pp 79-90. New York: Liss.
Faissner AW, Kruse J (1990) J1/tenascin is a repulsive substrate for central nervous system neurons. Neuron 5:627-637.

Faissner A, Steindler DA (1995) Boundaries and inhibitory molecules in developing neural tissues. Glia 13:233-254.

Faissner A, Clement A, Lochter A, Streit A, Mandl C, Schachner M (1994) Isolation of a neural chondroitin sulfate proteoglycan with neurite outgrowth-promoting properties. J Cell Biol 126:783-799.

Fawcett JW (1989) Oligodendrocytes repel axons and cause axonal growth cone collapse. J Cell Sci 92:93-100.

Fichard A, Verna J-M, Olivares J, Saxod R (1991) Involvement of chondroitin sulfate proteoglycan in the avoidance of chick epidermis by dorsal root ganglia fibers: a study using beta-D-xyloside. Dev Biol 148:1-9.

Gates MA, O’Brien TF, Faissner A, Steindler DA (1993) Neuron-glial interactions during the in vivo and in vitro development of the nigrostriatal circuit. J Chem Neuroanat 6:179-189.

Gates MA, Laywell ED, Fillmore H, Steindler DA (1996) Astrocytes and extracellular matrix in adult mice following intracerebral transplantation of embryonic ventral mesencephalon or lateral ganglionic eminence. Neuroscience 74:579-597.

Gotz B, Scholze A, Clement A, Joester A, Schutte K, Wigger F, Frank R, Spiess E, Ekblom P, Faissner A (1996) Tenascin-C contains distinct adhesive, antiadhesive, and neurite outgrowth-promoting sites for neurons. J Cell Biol 132:681-699.

Grierson JP, Petroski RE, Ling DSF, Geller HM (1990) Astrocyte topography and tenascin/cytotactin expression: correlation with the ability to support neuritic outgrowth. Development (Camb) 55:11-19.

Hatten ME, Liem RKH, Shelanski ML, Mason CA (1991) Astroglia in CNS injury. Glia 4:233-243.

Herndon ME, Lander AD (1990) A diverse set of developmentally regulated proteoglycans is expressed in the rat central nervous system. Neuron 4:949-961.

Hoffman S, Edelman GM (1987) A proteoglycan with HNK-a antigenic determinants is a neuron-associated ligand for cytotactin. Proc Natl Acad Sci USA 84:2523-2527.

Hoffman S, Crossin KL, Edelman GM (1988) Molecular forms, binding functions, and developmental expression patterns of cytotactin and cytotactin-binding proteoglycan, an interactive pair of extracellular matrix molecules. J Cell Biol 106:519-532.

Husmann K, Faissner A, Schachner M (1992) Tenascin promotes cerebellar granule cell migration and neurite outgrowth by different domains in the fibronectin type III repeats. J Cell Biol 116:1475-1486.

Iijima N, Oohira A, Mori T, Kitabatake K, Kohsaka S (1991) Core protein of chondroitin sulfate proteoglycan promotes neurite outgrowth from cultured neocortical neurons. J Neurochem 56:706-708.

Krull C, Oland L, Faissner A, Schachner M, Tolbert L (1994) In vitro analyses of neurite outgrowth indicate a potential role for tenascin-like molecules in the development of insect olfactory glomeruli. J Neurobiol 25:989-1004

Langenfeld-Oster B, Faissner A, Irintchev A, Wernig A (1994) Polyclonal antibodies against N-CAM and tenascin delay endplate reinnervation. J Neurocytol 23:591-604.

Laywell E, Steindler DA (1991) Boundaries and wounds, glia and glycoconjugates: cellular and molecular analyses of developmental partitions and adult brain lesions. Ann NY Acad Sci 633:122-141.

Laywell ED, Dörries U, Bartsch U, Faissner A, Schachner M, Steindler DA (1992) Enhanced expression of the developmentally regulated extracellular matrix molecule tenascin following adult brain injury. Proc Natl Acad Sci USA 89:2634-2638.

Laywell E, Friedman P, Harrington K, Robertson J, Steindler D (1996) Cell attachment to frozen sections of injured adult mouse brain: effects of tenascin antibody and lectin perturbation of wound-related extracellular matrix molecules. J Neurosci Methods 66:99-108.

Le Roux P, Reh T (1994) Regional differences in glial-derived factors that promote dendritic outgrowth from mouse cortical neurons in vitro. J Neurosci 14:4639-4655.

Letourneau PC, Condic ML, Snow DM (1994) Interactions of developing neurons with extracellular matrix. J Neurosci 14:915-928.

Lindsay R (1979) Adult brain astrocytes support survival of both NGFdependent and NGF-insensitive neurons. Nature 282:80-82.

Lindsay RM, Barber PC, Sherwood MRC, Zimmer J, Raisman G (1982) Astrocyte cultures from adult rat brain. Derivation, characterization, and neurotrophic properties of pure astroglial cells from corpus callosum. Brain Res 243:329-343. 
Lochter A, Vaughan L, Kaplony A, Prochiantz A, Schachner M, Faissner A (1991) J1/tenascin in substrate-bound and soluble form displays contrary effects on neurite outgrowth. J Cell Biol 113:1159-1171.

Logan A, Frautschy SA, Gonzalez A-M, Sporn MB, Baird A (1992) Enhanced expression of transforming growth factor $\beta 1$ in the rat brain after a localized cerebral injury. Brain Res 587:216-225.

McAdams B, McLoon S (1995) Expression of chondroitin sulfate and keratan sulfate proteoglycans in the path of growing retinal axons in the developing chick. J Comp Neurol 352:584-606.

McKeon RJ, Schreiber J, Rudge JS, Silver J (1991) Reduction of neurite outgrowth in a model of glial scarring following CNS injury is correlated with the expression of inhibitory molecules on reactive astrocytes. J Neurosci 11:3398-3411.

Meiners S, Marone M, Rittenhouse J, Geller H (1993) Regulation of astrocytic tenascin by basic fibroblast growth factor. Dev Biol 160:480-493.

Meiners S, Powell E, Geller H (1995) A distinct subset of tenascin/CS6-PG-rich astrocytes restricts neuronal growth in vitro. J Neurosci 15:8096-8106.

Mendenhall W (1975) Introduction to probability and statistics. North Scituate, MA: Duxbury.

Norenberg MD (1994) Astrocyte responses to CNS injury. J Neuropathol Exp Neurol 53:213-220.

Oakley RA, Tosney KW (1991) Peanut agglutinin and chondroitin-6sulfate are molecular markers for tissues that act as barriers to axon advance in the avian embryo. Dev Biol 147:187-206.

Oohira A, Matsui F, Matsuda M, Takida Y, Kuboki Y (1988) Occurrence of three distinct molecular species of chondroitin sulfate proteoglycan in the developing rat brain. J Biol Chem 263:10240-10246.

Pearson CA, Pearson D, Shibahara S, Hofsteenge J, Chiquet-Ehrismann R (1988) Tenascin: cDNA cloning and induction by TGF-beta. EMBO J 7:2977-2981.

Pindzola R, Doller C, Silver J (1993) Putative inhibitory extracellular matrix molecules at the dorsal root entry zone of the spinal cord during development and after root and sciatic nerve lesions. Dev Biol 156:34-48.

Pixley SKR, de Vellis J (1984) Transition between immature radial glia and mature astrocytes studied with a monoclonal antibody to vimentin. Dev Brain Res 15:201-210.

Qian J, Bull M, Levitt P (1992) Target-derived astroglia regulate axonal outgrowth in a region-specific manner. Dev Biol 149:278-294.

Reier PJ, Houle JD (1988) The glial scar: its bearing on axonal regeneration and transplantation approaches to CNS repair. In: Advances in neurology: functional recovery in neurological disease (Waxman SG, ed), pp 87-138. New York: Raven.

Reier PJ, Stensaas LJ, Guth L (1983) The astrocytic scar as an impediment to regeneration in the central nervous system. In: Spinal cord reconstruction (Kao CC, Bunge RP, Reier PJ, eds), pp 163-195. New York: Raven.

Rudge JS, Silver J (1990) Inhibition of neurite outgrowth on astroglial scars in vitro. J Neurosci 10:3594-3603.

Rudge JS, Smith GM, Silver J (1989) An in vitro model of wound healing in the CNS: analysis of cell reaction and interaction at different ages. Exp Neurol 103:1-16.

Schnell L, Schwab ME (1990) Axonal regeneration in the rat spinal cord produced by an antibody against myelin-associated neurite growth inhibitors. Nature 343:269-272.
Schwab ME, Kapfhammer JP, Bandtlow CE (1993) Inhibitors of neurite growth. Annu Rev Neurosci 16:565-595.

Smith GM, Miller RH, Silver J (1986) Changing role of forebrain astrocytes during development, regenerative failure, and induced regeneration upon transplantation. J Comp Neurol 251:23-43.

Snow DM, Letourneau PC (1992) Neurite outgrowth on a step gradient of chondroitin sulfate proteoglycan (CS-PG). J Neurobiol 23:322-336.

Snow DM, Lemmon V, Carrino DA, Kaplan AI, Silver J (1990a) Sulfated proteoglycans in astroglial barriers inhibit neurite outgrowth in vitro. Exp Neurol 109:111-130.

Snow DM, Steindler DA, Silver J (1990b) Molecular and cellular characterization of the glial roof plate of the spinal cord and optic tectum: a possible role for a proteoglycan in the development of an axon barrier. Dev Biol 138:359-376.

Spring J, Beck K, Chiquet-Ehrismann R (1989) Two contrary functions of tenascin: dissection of the active sites by recombinant tenascin fragments. Cell 59:325-334.

Steindler DA (1993) Glial boundaries in the developing nervous system. Annu Rev Neurosci 16:445-470.

Steindler DA, Cooper NGF, Faissner A, Schachner M (1989a) Boundaries defined by adhesion molecules during development of the cerebral cortex: the $\mathrm{J} 1 /$ tenascin glycoprotein in the mouse somatosensory cortical barrel field. Dev Biol 131:243-260.

Steindler DA, Faissner A, Schachner M (1989b) Brain "cordones": glial and adhesion molecule-transient boundaries define developing functional units. Comments Dev Neurobiol 1:29-60.

Steindler DA, O'Brien TF, Laywell E, Harrington K, Faissner A, Schachner M (1990) Boundaries during normal and abnormal brain development: in vivo and in vitro studies of glia and glycoconjugates. Exp Neurol 109:35-56.

Steindler DA, Settles D, Erickson HP, Laywell ED, Yoshiki A, Faissner A, Kusakabe M (1995) Tenascin knockout mice: barrels, boundary molecules, and glial scars. J Neurosci 15:1971-1983.

Taylor J, Pesheva P, Schachner M (1993) Influence of janusin and tenascin on growth cone behavior in vitro. J Neurosci Res 35:347-362.

Thomas L, Steindler D (1995) Glial boundaries and scars: programs for normal development and wound healing in the brain. The Neuroscientist 1:142-154.

Weller A, Beck S, Ekblom P (1991) Amino acid sequence of mouse tenascin and differential expression of two tenascin isoforms during embryogenesis. J Cell Biol 112:355-362.

Windle W, Clemente C, Chambers W (1952) Inhibition of formation of a glial barrier as a means of permitting a peripheral nerve to grow into the brain. J Comp Neurol 96:359-369.

Zang Y, Campbell G, Anderson P, Martini R, Schachner M, Lieberman A (1995) Molecular basis of interactions between regenerating adult rat thalamic axons and Schwann cells in peripheral nerve grafts. II. Tenascin-C. J Comp Neurol 361:210-224.

Zwimpfer T, Aguayo A, Bray G (1992) Synapse formation and preferential distribution in the granule cell layer by regenerating retinal ganglion cell axons guided to the cerebellum of adult hamsters. J Neurosci 12:1144-1159. 